\title{
Ex-Officio Members
}

David Easterbrook (CAMP)

African Studies Area Specialist

Indiana University Lib., E660

Bloomington, IN 47405

(812) 335-1481

Kay Elsasser, Chairperson

Cataloging \& Classification S-C

Subject Cataloging Division

Library of Congress

Washington, D.C. 20540

(202) 287-5887

Yvette Scheven

328 Library

University of Illinois

Urbana, IL 61801

(217) 333-6519
Beverly Gray (Library of Congress)

Head, African Section

Library of Congress

Washington, D.C. 20540

(202) 287-5528/9

Joseph Lauer, Chairperson

Bibliography Sub-Committee

African Studies Bibliographer

UCLA Library

Los Angeles, CA 90024

(213) $825 \cdot 1518$

Leon Spencer, Archivist

Historical Collections

Talladega College

Talladega, AL 35167

(205) $362-0206 \times 283$

The Archives-Libraries Committee has named Kay Elsasser of the Library of Congress to represent the African Studies Association for the next two years on the Committee on Cataloging of the American Library Association. She replaces Gail Junion, who has served in that capacity for the past four years.

\section{OBITUARY}

\section{YVES PERSON}

12 OCTOBER, 1925 - 17 NOVEMBER, 1982

THE TIMES OF LONDON, November 26, 1982, page 14.

\section{"Professor Yves Person"}

Professor Yves Person, Professor of African History at the Sorbonne, died on November 17 at the age of 56 . He is remembered by many friends in the United Kingdom as the author of an epoch-making work of scholarship and as a warmly vibrant speaker on African topics, continually switching from French to English in impassioned pleas for an international order which would acknowledge the fundamental rights of all "primary nations," and a European community devoted to "un socialisme de la difference."

Yves Person was born on 12 October, 1925. His father, to whose memory he dedicated, in Breton, his magnum opus, was an officer who took part in the military "pacification" of the Ivory Coast after 1908, and he himself entered the colonial service in 1948. He devoted great energy and talent to the study of the history, languages and ethnography of the peoples among whom he served. From 1955, he became preoccupied with the study of the history of the Manding peoples, and above all with the figure of Samori. 
This man, known to Europeans as a skillful and fierce military opponent of the French conquest, assumes much greater significance through Manding eyes as the creator of a large Muslim empire whose revolutionary character derived from the support of the widely-dispersed diaspora of the traders known as dyula. While performing his administrative duties Person embarked on a massive study which placed Samori firmly in the context of the internal history of West Africa, as well as that of European Imperialism.

In 1961 he was detached from the administrative service to pursue his study of oral traditions. In 1967 he became Professor of History at Dakar University and in 1970 succeeded to the chair at the Sorbonne.

Samori: Une Revolution Dyula runs to 2,377 large pages in three somewhat daunting volumes, but its insights have influenced all students of the period. By exploring the Manding past in such deep particularity Person hoped to atone for injuries which members of his own submerged nationality, the Bretons, had inflicted on other peoples in the service of the centralized French state.

This over-riding concern for justice to every human group occasionally led Person to write on topics where his commitment outran his detailed knowledge; during the Nigerian Civil War he sometimes seemed to confuse the Biafran case with that of Brittany.

A former member of the PSU, the small left-wing party, Person transferred his energetic support to the Socialist Party once it had recognized the problems of minorités nationales within France, and served on committees evolving policies for regional devolution and linguistic pluralism. 